\section{TARA FORREST \\ criticism, theory and the
'guiding star' of \\ mimesis}

\begin{tabular}{l} 
LALEEN JAYAMANNE \\
\begin{tabular}{|l} 
Toward Cinema and Its Double: Cross-Cultural \\
Mimesis
\end{tabular} \\
\begin{tabular}{|l} 
Indiana University Press, Bloomington, 2001 \\
\hline ISBN 0-253-21475-0
\end{tabular} \\
\hline RRP US $\$ 22.95(\mathrm{pb})$
\end{tabular}

As Laleen Jayamanne notes at various points throughout the book, the impetus driving the dynamic - certainly idiosyncratic-conception of film criticism which emerges from this collection of essays and interviews is a dissatisfaction with what she describes as the split between 'film criticism' and 'film theory' apparent within academic film studies. In an interview with Therese Davis on the occasion of the book's release, Jayamanne traces this split to the institutionalisation of film studies in the 1970s and, more specifically, to the manner in which academic film studies sought to legitimise itself through theory. 1 While this 'strategic move' was certainly enabling for the establishment of film studies as a discipline, Jayamanne argues that this prioritisation of theory has led to an 'impoverishment of cinema' within which the filmic object is called upon only to 'dutifully ... prove the propositions of theory'. (53)

The example to which she returns throughout the course of the book is the development, in the 1970s, of feminist film theory inspired by psychoanalysis. Citing Laura Mulvey's influential article 'Visual Pleasure and Narrative Cinema'2 as an example, Jayamanne argues that although feminist film theory of this period opened up ways of thinking about film which were certainly enabling, its 'colonisation' of its object left little, if any, space within which film could be said to communicate on its own terms, that is, outside the sometimes rigid parameters set in place by feminist analysis. At the heart of her criticism of the latter stands the figure of the 'knowing critic', the traces of whom she also locates in 'a certain kind of cultural studies' within which "large claims about general trends 
in culture (to do with "race", "gender", "class", and "ethnicity")' are made at the expense of the specificity of the filmic object. (206) What is troubling, for Jayamanne, about the prioritisation of theory characteristic of each of these modes of analysis is that little attention is paid to the filmic object in its own right-to 'its capacity to surprise in ways unknown and perhaps unknowable to theory'. (53)

The articles collected in the book (which were written over a twenty-year period) are each the result of Jayamanne's attempts 'to discard the straitjacket of the "knowing critic" (207) in her analysis of cinema. 'This is a book of film criticism, nothing but film criticism', she writes in her introduction to the collection. As she goes on to explain, "What this means is that the filmic object under consideration is of primary value' (xi):

[A]s a film critic I must confess that I cannot make a single move without an involvement in an aural or visual image. While this may well be a personal idiosyncrasy, I would also like to make one large claim (a truism, really) for cinema and film studies, 'my field.' Its coherence as a discipline must depend on, at least, an attentiveness to the object, film: on, dare I say, the primacy even of the object. (206)

In her analysis of an eclectic selection of films (from Australia, Sri Lanka, Italy, France, Belgium and the USA) Jayamanne's 'attentiveness' to her object of study is demonstrated through the importance she places upon 'description' as a tool for both entering and re-presenting the 'materiality' of the filmic object. She argues that rather than taking her cue from theory, it is from her own detailed descriptions-one might say translations - of the films themselves (and their 'materiality of movement, rhythm, color, light, sound and duration') that a reading begins to develop. (206)

It would be wrong, however, to suggest that the book is devoid of certain guiding theoretical frameworks. As Jayamanne states from the outset, Walter Benjamin's and Theodor Adorno's conception of mimesis (as magically revealed to her by Michael Taussig) 3 is 'an operative concept' and 'a guiding star' of the book. (xii) While she does (in her analysis of Roberto Rossellini's Paisan, Jane Campion's The Piano, and the films of Charlie Chaplin) discuss the ways in which the capacity to both perceive and create similarities operates at the level of character, as stated in the introduction, her aim is not to discuss mimesis as 'a category', but to 'try to activate its bio-anthropological, impulsive, performative vitalism in the act of criticism itself'. (xii) This is achieved not only through Jayamanne's 'exact' descriptions of scenes and moments (which she describes as 'mimetic double[s]' of the original object) but through the opening up of time enabled by mimetic forms of perception. (xv)

This emphasis on the expansion of one's experience of time precipitated by a mimetic mode of engagement is discussed in detail in Parts Four and Five of the book, in which Jayamanne draws on ideas developed in Gilles Deleuze's writings on cinema 4 to explore 'the aconceptual yield of images' which is revealed when a perception of time becomes separated from action. (xiv) For Jayamanne, the chapters included in these sections (which explore films as diverse as Kathryn 
Bigelow's Blue Steel, Chantal Akerman's Jeanne Dielman, 23 Quai du Commerce, 1080 Bruxelles, Spike Lee's Do the Right Thing, and Raul Ruiz's Three Crowns of a Sailor) 'mark the move from thinking of film as a textual system to thinking of it as an art of movement and of duration'. (xiv) Following Deleuze, she argues that it is through a disturbance of narrative time that an encounter with the image that resists conceptualisation is able to occur. 'If we concede this experience', she claims that we must acknowledge that 'there is a gap between the seeable and the sayable', and that ' $[\mathrm{t}$ ] $\mathrm{o}$ acknowledge this gap is ... a way of conceding the role of mimetic mentorship to film'. (223)

And yet, if we are to take seriously Jayamanne's claim that Benjamin's and Adorno's conception of mimesis is 'a guiding star' for the book, then there are points in this book in which much more could have been said about the politics of mimesis and where mimetic forms of perception might take us. Although Jayamanne discusses and enacts, in detail, the relationship between cinema and the mimetic forms of knowledge which it enables, the ways in which these knowledges could be brought to bear on the exigencies of the present is often elided or understated. In the light of Jayamanne's claim that '[t]his is a book of film criticism, nothing but film criticism', my concerns in this regard may be illfounded. I do think, however, that it would be a shame for film studies to risk-in the name of film studies itself_-distancing its concerns from the active politics for which feminist film theory of the 1970s stood so strongly.
TARA FORREST teaches Cultural Studies at the University of Technology, Sydney, and is currently undertaking a joint PhD in the Department of German Studies and the School of Theatre, Film and Dance at the University of New South Wales.

1. Therese Davis, 'Interview with Laleen Jayamanne', Senses of Cinema, issue 21, July/August 2002.

2. Laura Mulvey, 'Visual Pleasure and Narrative Cinema', Screen, vol. 16, no. 3, Autumn 1975.

3. Michael Taussig, Mimesis and Alterity: A Particular History of the Senses, Routledge, New York and London, 1993.

4. Gilles Deleuze, Cinema 1: The Movement Image, trans. Hugh Tomlinson and Barbara Habberjam, University of Minnesota Press, Minneapolis, 1996, and Cinema 1: The Time Image, trans. Hugh Tomlinson and Robert Galeta, University of Minnesota Press, Minneapolis, 1995. 